\title{
Effect of alternating the magnetic field on phosphate metabolism in the nervous system of Helix pomatia
}

\author{
Ljiljana M Nikolic ${ }^{1}$, Milos B Rokic ${ }^{2}$, Natasa V Todorovic ${ }^{1}$, Gordana S Kartelija ${ }^{1}$, Miodrag S \\ Nedeljkovic ${ }^{1}$ and Joanna S Zakrzewska ${ }^{3}$
}

'Department of Neurophysiology, Institute for Biological Research "Sinisa Stankovic", University of Belgrade, Bulevar Despota Stefana 142, 11060 Belgrade, Serbia, Institute for Multidisciplinary Studies, Kneza Viseslava 1, 11030 Belgrade, Serbia, ${ }^{3}$ Institute of General and Physical Chemistry, Studentski trg 12-16, 11000 Belgrade, Serbia

\begin{abstract}
The effect of extremely low frequency magnetic fields $(50 \mathrm{~Hz}, 0.5 \mathrm{mT})$ - ELF-MF, on phosphate metabolism has been studied in the isolated ganglions of the garden snail Helix pomatia, after 7 and 16 days of snail exposure to ELF-MF. The influence of ELF-MF on the level of phosphate compounds and intracellular $\mathrm{pH}$ was monitored by ${ }^{31} \mathrm{P}$ NMR spectroscopy. Furthermore, the activity of enzymes involved in phosphate turnover, total ATPases, $\mathrm{Na}^{+} / \mathrm{K}^{+}$-ATPase and acid phosphatase has been measured. The exposure of snails to the ELF-MF for the period of 7 days shifted intracellular $\mathrm{pH}$ toward more alkaline conditions, and increased the activity of investigated enzymes. Prolonged exposure to the ELF-MF for the period of 16 days caused a decrease of PCr and ATP levels and decreased enzyme activity, compared to the 7-day treatment group. Our results can be explained in terms of: 1 . increase in phosphate turnover by exposure to the ELF-MF for the period of 7 days, and 2. adaptation of phosphate metabolism in the nervous system of snails to prolonged ELF-MF exposure.
\end{abstract}

Key terms: ELF-MF, garden snail, ${ }^{31} \mathrm{P}$ NMR spectroscopy, phosphate turnover enzymes.

\section{INTRODUCTION}

In recent decades scientific interest in the effect of static and alternating magnetic fields on the biological systems has increased. Various strengths of magnetic fields are investigated for their biological effects, but mostly at the strength of the Earth's magnetic field (35- $70 \mu \mathrm{T})$ and, much higher, man-made magnetic fields that are normally present in our environment. This interest arises from the fact that all living organisms are constantly exposed to the Earth's and man-made magnetic fields (Table 1).

The ability of biological systems to detect the Earth's magnetic field is found in diverse invertebrates and vertebrates and is important for compass orientation of animals (Katz and Yilks, 1979; Mather and Baker, 1981; Zoeger et al., 1981; Blakemore, 1982; Mathis and Moore, 1984; Lohman and Willows, 1991; Wang et al., 2002). Furthermore, numerous studies have explored the interaction of man-made static and alternating magnetic fields with biological systems. Previous research showed that these magnetic fields can induce changes in behavior (Rudolph et al., 1985; Prato et al., 1996; Janac et al., 2005), enzyme activity (Nossol et al, 1993; Blank and Soo, 1996; Liboff et al., 2003; Chen et al., 2009), the synthesis and release of neurohormons (Peric-Mataruga et al., 2008), biophysical properties of neurons (McLean et al., 1995; Calvo and Azanza, 1999; Ye et al., 2004; Todorovic et al., 2007), synaptic transmission (Rosen, 1992) and ion channel currents (Shen et al., 2007). Furthermore, magnetic field influence on nucleic acids and protein synthesis has been found (Cridland et al., 1999; Ciombor et al., 2002; Hirai et al., 2002; Schmitz et al., 2004). However, little is known about magnetic field effect on the phosphate metabolism of the nervous system.

In order to test the effect of magnetic fields on nervous system metabolism, we chose the nervous system of the snail Helix pomatia, which is a welldescribed model system for neurophysiological studies (Rozsa 1984, Altrup 2004). As we have already shown, neuronal membrane properties of Helix pomatia are influenced by static magnetic fields (Nikolic et al., 2008). Other studies have documented that magnetic fields induce changes in the bioelectric properties of snail neurons (Balaban et al., 1990; Moghadam et al., 2008; Ayrapetyan et al., 2004). As is known, the firing properties of neurons and electrical signaling between cells imply specific energy demands (Magistretti, 2003). Furthermore, maintenance of the electrochemical gradient, 
Table 1

Magnetic flux densities of Earth and some man-made magnetic fields

\begin{tabular}{l|l}
\hline Natural magnetic field & $(\mu \mathrm{T})$ Man-made Magnetic fields \\
\hline Earth magnetic field 35-70 & Hair dryers 6 - 2000 \\
\hline & Electric shavers $15-1500$ \\
\hline & Vacuum cleaners $200-800$ \\
\hline & Mixers 60 - 700 \\
\hline & Industrial processes $0.7-6000^{*}$ \\
\hline
\end{tabular}

Examples of some magnetic flux densities (units in $\mu \mathrm{T}$ ) near various home appliances measured at the distance of $3 \mathrm{~cm}$; ${ }^{*}$ distance measured at 0.1-2 m.

According to environmental health criteria of the World Health Organization, Geneva, http://www.inchem.org/documents/ehc/ehc/ehc69.htm\#SubSectionNumber:3.2.1)a

particularly for $\mathrm{Na}^{+}$and $\mathrm{K}^{+}$ions by $\mathrm{Na}^{+} / \mathrm{K}^{+}$-ATPase, is the main energy consuming process in neuronal cells. Moreover, the energy status of the cell influences bioelectrical properties of the membrane (Lara et al., 1999).

We wanted to test whether magnetic fields of extremely low frequency $(50 \mathrm{~Hz})$ and of a magnetic flux density of $0.5 \mathrm{mT}$ (ELF-MF) would have effects on the nervous system metabolism of $H$. pomatia. As can be seen from Table 1, alternating magnetic fields of similar strength can be encountered in the vicinity of various home appliances.

In order to explore whether exposure to ELFMF can cause changes in the level of phosphate compounds in the nervous system of the snail, we used the ${ }^{31} \mathrm{P}$ NMR spectroscopy, which provides direct information about tissue energy metabolism and indirect data from intermediary metabolism. To investigate ELF-MF influence in more detail, some of the enzymes involved in phosphate (P) turnover were also explored. So far, several reports about magnetic field influence on the activity of enzymes involved in $\mathrm{P}$ turnover have been reported (Blank and Soo, 1996; Chen et al., 2009). We have chosen to explore the total ATPases, $\mathrm{Na}^{+} / \mathrm{K}^{+}$-ATPase and acid phosphatase enzymes in the snail nervous system.

\section{METHODS}

\section{Experimental Design}

The ${ }^{31} \mathrm{P}$ NMR and enzyme activity analysis were performed on the isolated ganglion complex of the garden snail Helix pomatia (Pulmonata: Helicidae). Snails used for all experiments were collected at spring, placed in polycarbonate boxes and kept in the cold chamber at $7{ }^{\circ} \mathrm{C}$. The experiments were conducted in the winter period, because snail activity and variations in snail physiology, as seen by variations in the texture and rigidity of connective sheets, are minimal in the winter months. In this way the effects of seasonal changes in snail physiology are greatly minimized. Four weeks prior to the experiments, snails were acclimated at $22{ }^{\circ} \mathrm{C}$, kept in an active state, and fed regularly.

An experimental group composed of randomly selected snails of similar age (with a shell diameter of approximately $4 \mathrm{~cm}$ ) was placed in a polycarbonate box ( $26 \mathrm{~cm}$ wide $x 43 \mathrm{~cm}$ long x $15 \mathrm{~cm}$ high) in a temperature controlled room $\left(22 \pm 1{ }^{\circ} \mathrm{C}\right)$ and exposed to the ELF-MF as shown in Figure 1.

For the purpose of ${ }^{31} \mathrm{P}$ NMR analysis, the single group of snails $(n=20)$ was exposed to the ELFMF. After 7 days of exposure, 10 randomly selected snails were used for recording NMR spectrum, another 10 snails were further exposed to the ELFMF up to 16 days, and another NMR spectrum was recorded. Immediately afterwards, a control group was formed by placing 8 snails at the same position as the exposed group, but the source of ELF-MF was turned off and unplugged from its power supply (sham exposure) for 7 days, after which the control NMR spectrum was recorded.

A similar procedure was used for biochemical analysis. The only difference was the number of snails: 3 animals out of group of 7 snails were used for enzyme activity analysis after 7 days of ELFMF exposure, and the remaining 4 snails were used for enzyme activity analysis after 16 days. The control group $(n=5)$, placed at the same position as the ELF-MF treated group, was sham exposed for a period of 7 days, immediately after the 16-day treatment.

Ganglion complexes were isolated as previously described in Nikolic et al (2008). Briefly, after the snail foot was separated, it was pinned onto a cork plate in the extended position. Incision at the dorsal anterior surface of the snail's foot enabled 

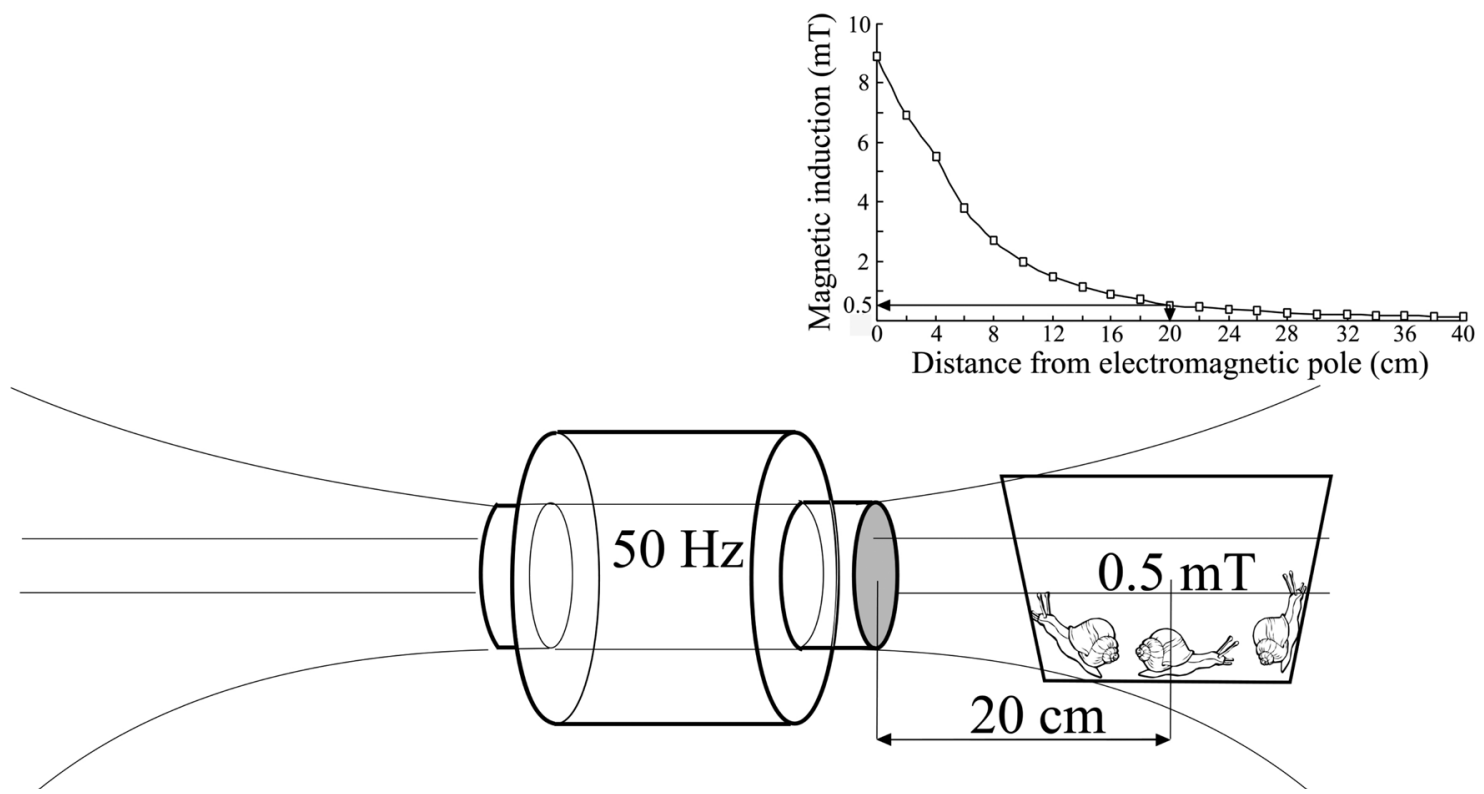

Figure 1. ELF-MF exposure system (electromagnet and box with snails) with marked magnetic force lines. Inset: change of the magnetic induction within the box with snails.

access to the ganglion complex. In order to prevent tissue degradation, the isolated ganglions were kept in snail physiological solution on ice prior to measurements.

The source of ELF-MF was placed approximately $20 \mathrm{~cm}$ from the center of the box with snails (Fig. 1). Alternating magnetic fields were generated by a solenoid-type electromagnet with a regular laminated transformer core and pole dimensions of $9.5 \mathrm{~cm} \times 9.5 \mathrm{~cm}$. A $50 \mathrm{~Hz}$ sinusoidal current $(40 \mathrm{~V}, 4.5$ A) was passed through the magnet. The alternating magnetic field was not uniform in the exposure space (Fig. 1), but an average magnetic induction was $0.5 \mathrm{mT}$ at the middle of the polycarbonate box, a value in the magnitude found in the vicinity of home appliances (Table1) (measured by a Hirst GM05 Gaussmeter, using a PT2837 probe). The temperature difference between ELF-MF treated and sham exposed groups, in the exposure space, was less than $0.3{ }^{\circ} \mathrm{C}$ measured in the air, and no difference was found measured in the liquid.

Magnetic force lines were parallel to the horizontal component of the local geomagnetic field. Earth magnetic field strength, measured by a GSM 10 proton magnetometer (Geomagnetic Institute - Grocka, Belgrade), was within the normal range throughout experiments in the area of study (44 $38^{\prime}$ $\left.\mathrm{N}, 20^{\circ} 46^{\prime} \mathrm{E}\right)$. The background magnetic field did not exceed the value of $10^{-5} \mathrm{mT}$.

Exposure time was chosen based on the previous experiments, showing that a $0.5 \mathrm{mT}$ alternating magnetic field can induce behavioral effects, as well as biochemical changes in the brains of rats exposed for as little as 7 days (Janać et al., 2005; Jelenković et al., 2006).

\section{${ }^{31}$ P NMR spectroscopy}

${ }^{31} \mathrm{P}$ NMR measurements were performed using a Bruker MSL 400 (Germany), Apollo upgraded (Tecmag, USA) spectrometer operating at 161.978 $\mathrm{MHz}$ for ${ }^{31} \mathrm{P}$. The other experimental conditions were: $15 \mu$ s pulse width $\left(45^{\circ}\right)$, relaxation delay of $300 \mathrm{~ms}, 8 \mathrm{KHz}$ spectral width. Under such conditions, peaks are partially saturated, however, data were analyzed only in terms of relative changes and there are no reasons to assume that the relaxation times of different components change. Each spectrum represents 4000 acquisitions averaged over 20 minutes. The line broadening of $25 \mathrm{~Hz}$ was applied with Fourier transformation. The isolated snail ganglions (about $5.8 \mathrm{~g}$ ) were packed in the $10 \mathrm{~mm}$ NMR tube filled with physiological snail solution $(80 \mathrm{mM} \mathrm{NaCl}, 5 \mathrm{mM}$ $\mathrm{MgCl}_{2}, 10 \mathrm{mM} \mathrm{CaCl}, 4 \mathrm{mM} \mathrm{KCl}$, and $5 \mathrm{mM}$ Tris (hydroxymethyl) aminomethane. Capillary with methylenediphosphonate, MDP (25 mM) was used as an external chemical shift (17.05 ppm relatively to $85 \% \mathrm{H}_{3} \mathrm{PO}_{4}$ ) and peak intensity standard. It should be mentioned that during experiments there were no changes in the chemical shift and line width of the MDP reference signal, which is in agreement with reported independence of these parameters on the magnetic susceptibility of the solution in the 
outer tube under similar experimental conditions (Fabry and San George, 1983). All chemicals used for ${ }^{31} \mathrm{P}$ NMR spectroscopy were supplied from Merck (Germany). The ${ }^{31} \mathrm{P}$ NMR spectra for the control and 7-day and 16-day ELF-MF exposed groups of snails were obtained from 8 to 10 ganglions, and represent average status of the ganglions used.

Intracellular $\mathrm{pH}$ value was estimated according to Mimura and Kirino (1984).

\section{Enzyme assays}

Analysis of enzyme activity was performed on isolated, individual snail ganglions. Each ganglion with a weight of approximately 61 $\mathrm{mg}$ was analyzed in triplicate. Ganglion tissue was homogenized in $0.7 \mathrm{~mL}$ Tris- $\mathrm{HCl}$ buffer at $\mathrm{pH}$ of 7.4 with $0.01 \%$ Triton $\mathrm{X}-100$. The homogenate was centrifuged in refrigerated in an Eppendorf microcentrifuge, model 5415R, at $10000 \mathrm{rpm}$. The supernatant was used for enzyme activity measurements. Protein content was determined by the method of Bradford using BSA as standard proteins (Bradford, 1976). The activity of investigated enzymes was measured using a Shimadzu UV-2501 PC spectrophotometer (Shimadzu Scientific Instruments, Japan).

ATPase activity was determined by measuring ATP decomposition to inorganic phosphate and ADP. Three reaction mixtures were set, one experimental and two controls. The reaction was started by adding $70 \mu \mathrm{g}$ of total proteins from isolated ganglions into the final volume of the reaction mixture. The experimental reaction mixture contained: $40 \mathrm{mM} \mathrm{KCl}, 10 \mathrm{mM}$ ATPMg, $10 \mathrm{mM} \mathrm{MgCl}, 240 \mathrm{mM} \mathrm{NaCl}$, and $25 \mathrm{mM}$ Tris-Cl buffered at $\mathrm{pH}$ 7.4. First the control experiment was performed with the addition of $2 \mathrm{mM}$ ouabain and without $\mathrm{KCl}$, and the control experiment was performed without ATPMg. The reaction mixture was incubated at $22{ }^{\circ} \mathrm{C}$ for one hour and the reaction was stopped by adding SDS to a final concentration of $1 \%$. Inorganic phosphate was quantified by the method of Ohnishi et al. (1975) modified for microplate reader. The activity of ATPases was obtained as follows: the total ATPases were calculated by subtracting the probe absorbance from the total ATPases absorbance; by subtraction of the ouabain insensitive absorbance values from the total ATPases we obtained ouabain sensitive ATPases $\left(\mathrm{Na}^{+} / \mathrm{K}^{+}\right.$-ATPase).

Acid phosphatase activity was measured by the rate of p-nitrophenyl phosphate hydrolysis for 5 minutes by following absorbance at $405 \mathrm{~nm}$. The reaction was started by adding $200 \mathrm{mg}$ of total protein from isolated ganglions in the final volume of reaction mixture. The reaction mixture contained
$10 \mathrm{mM}$ acetate buffer ( $\mathrm{pH} 5.5$ ), $1 \mathrm{mM} \mathrm{MgCl}$, and 5 $\mathrm{mM}$ p-nitrophenyl phosphate. The p-nitrophenol concentrations were estimated by using extinction coefficient $18.5 \mathrm{~cm}^{2} / \mu \mathrm{mol}$.

All chemicals used for enzyme essays were supplied from Merck (Germany).

\section{${ }^{31} P N M R$ and enzyme essays data analysis}

In data analysis, the results of the control group of snails (7-day sham exposed) were compared to the results of 7-day treatment group. In order to monitor the effect of the ELF-MF for a longer period, the 16day treatment group was compared to the group of snails treated for 7 days.

Intensity of each ${ }^{31} \mathrm{P}$ NMR signal was calculated by NTNMR software (Tecmag, USA), and normalized to the intensity of the MDP signal. The errors of measurements were calculated as absolute errors. The error $D_{i}$ of normalized signal intensities $\mathrm{R}_{\mathrm{i}}$ was calculated as $\mathrm{D}_{\mathrm{i}}=\mathrm{R}_{\mathrm{i}}{ }^{*}((\mathrm{a} / \mathrm{MDP}$ intensity) + (a / signal intensity)), where $\mathrm{a}$ is the amplitude of noise, measured as $\Omega$ peak to peak, and $R_{i}$ is the signal intensity/ MDP intensity. We considered that ${ }^{31} \mathrm{P}$ NMR spectra normalized intensity values between compared groups were different if the sum of absolute errors was smaller than the difference between the intensities measured.

The differences in the enzyme activity ( $\mathrm{mmol} /$ mg'min) were evaluated by a one-way ANOVA (followed by Fisher LSD test). The significance was set at ${ }^{*} \mathrm{p}<0.05,{ }^{* *} \mathrm{p}<0.01$, and ${ }^{* * *} \mathrm{p}<0.001$. Error bars represent the standard error of the mean (SEM).

\section{RESULTS}

\section{${ }^{31} \mathrm{P}$ NMR spectroscopy}

The ${ }^{31} \mathrm{P}$ NMR spectrum of the isolated ganglion complex of the Helix pomatia snail is presented in Figure 2 and, to the best of our knowledge; this is the first recorded spectrum of the snail nervous system. Therefore, assignment of spectra signals was made by comparison to previously reported ${ }^{31} \mathrm{P}$ NMR spectra of the nervous systems of other species (Kauppinen and Williams, 1994; McNamara et al., 1994; Tsuji et al., 1995; Buck et al., 1998; Tsao et al., 1999). Obtained spectrum consists of signals that were assigned, from downfield, to: phosphomonoesters (PME), inorganic phosphate $(\mathrm{Pi})$, energy storage compound phosphocreatinin $(\mathrm{PCr})$, and nucleotide phosphates $(\alpha, \beta, \gamma$-ATP) involved in energy metabolism. The phosphomonoester peak consists mainly of phosphorylethanolamine (PE), with a smaller contribution from phosphorylcholine (PC). 


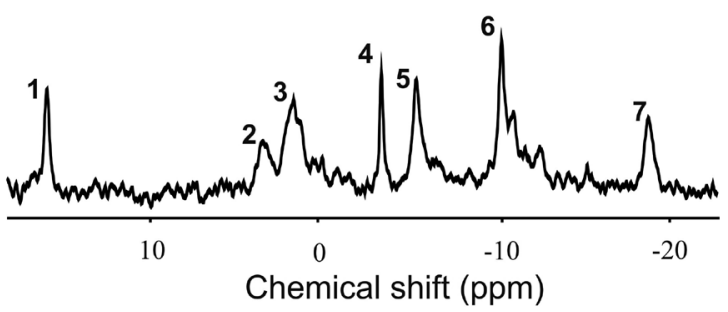

Figure 2. ${ }^{31} \mathrm{P}$ NMR spectrum of Helix pomatia isolated ganglion complex $(n=8)$. The signals are assigned to the following compounds: (1) Methylenediphosphonate (MDP, 17.05 ppm); (2) Phosphomonoesters (PME, $4.4 \mathrm{ppm}) ;(3)$ Inorganic phosphate ( $\mathrm{Pi}, 2.6 \mathrm{ppm}) ;(4)$ Phosphocreatine (PCr, -2.7 ppm); (5) $\gamma$-ATP (-4.7 ppm); (6) $\alpha$-ATP (-9.8 ppm); (7) $\beta$-ATP (-18.4 ppm).

The spectra of ganglion complexes for the control and 7-day and 16-day ELF-MF exposed snails are presented in Figure 3A, while quantitative representation is presented in Figure 3B.

As can be seen from the Figure $3 \mathrm{~B}$, the changes in the normalized intensities of phosphate compounds were not found between the control and the 7-day ELF-MF exposed group of snails (white and black bars). The important difference, between signals from the ganglions of control and 7-day ELF-MF exposed snails was the change in the chemical shift of the $P_{i}$ signal which is commonly used as an indicator of intracellular $\mathrm{pH}$ changes (Kauppinen and Williams, 1994) indicating intracellular $\mathrm{pH}$ change toward alkaline conditions, from about 6.9 to 7.1 in the 7-day ELF-MF exposed snails (Fig. 3A, vertical line).

However, when we compared the normalized signal intensities of the 7- and 16-day treatment groups (Fig. 3B, black and gray bars), the decrease in the intensity of the PCr and the ATP signals in the 16-day exposed group of snails was found. The intensity of the $\beta$-ATP signal was used for monitoring the energy status (ATP content), since $\gamma$ and $\alpha$ ATP signals overlap considerably with the $\beta$ and $\alpha$ resonance of ADP (Stubbs et al., 1996).

\section{Enzyme activity}

To further explore the influence of ELF-MF on the phosphate metabolism of the snail nervous system we investigated the activity of enzymes: total ATPases, $\mathrm{Na}^{+} / \mathrm{K}^{+}$-ATPase, and acid phosphatase.

The results presented in Figure 4 show that the activity of total ATPases significantly increased ( $p$ $<0.01, \mathrm{n}=3$ ) in the 7 -day treatment group of snails $\left(19.4 \times 10^{-6} \pm 8.4 \times 10^{-6} \mathrm{mmol} / \mathrm{mg} \times \mathrm{min}\right)$ compared to the control group $\left(2.1 \times 10^{-6} \pm 0.5 \times 10^{-6} \mathrm{mmol} / \mathrm{mg} \times \mathrm{min}\right)$. However, in the 16-day treatment group the significant decrease $(\mathrm{p}<0.05, \mathrm{n}=4)$ in the activity of total ATPases $\left(6.1 \times 10^{-6} \pm 2 \times 10^{-6} \mathrm{mmol} / \mathrm{mg} \times \mathrm{min}\right)$

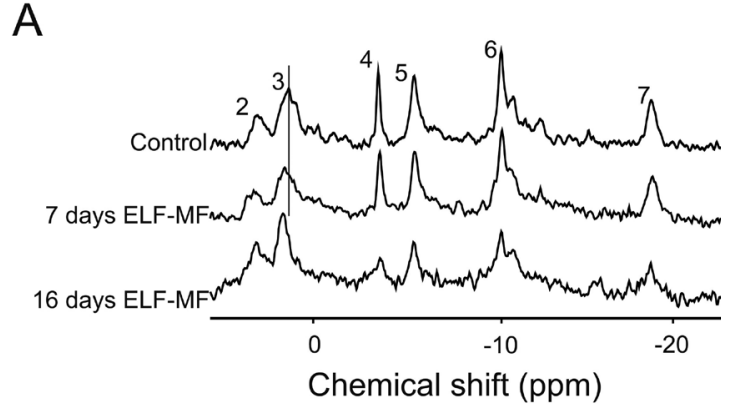

B

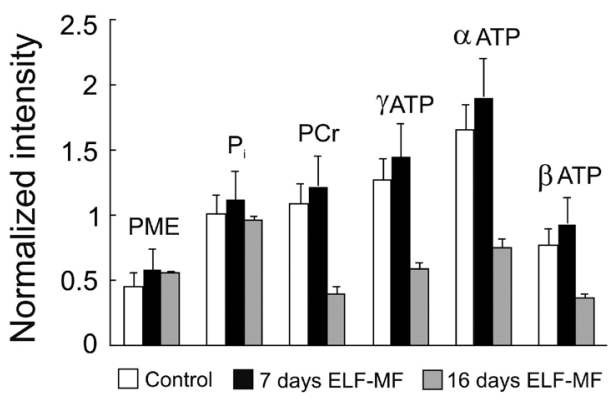

Figure 3. A. ${ }^{31} \mathrm{P}$ NMR spectra of Helix pomatia ganglion complex for the control $(n=8)$, 7-day $(n=10)$, and 16day $(n=10)$ ELF-MF $(50 \mathrm{~Hz}, 0.5 \mathrm{mT})$ exposed groups of snails. The vertical line represents the chemical shift of the Pi signal. B. Intensity of ${ }^{31} \mathrm{P}$ NMR signals normalized to the intensity of standard (MDP) for the control, 7-day and 16-day ELF-MF exposed groups of snails. Error bars represent the absolute errors.

compared to the 7-day treatment group was found. As well, Figure 4 shows the significant increase $(\mathrm{p}<0.05, \mathrm{n}=3)$ in the specific activity of $\mathrm{Na}^{+} / \mathrm{K}^{+}$ATPase in the 7-day treatment group $\left(9.5 \times 10^{-6} \pm 5\right.$ $\times 10^{-6} \mathrm{mmol} / \mathrm{mg} \times \mathrm{min}$ ) compared to the control group of snails $\left(1.2 \times 10^{-6} \pm 0.4 \times 10^{-6} \mathrm{mmol} / \mathrm{mg} \times \mathrm{min}\right)$. The difference between 7 - and 16-day treatment groups of snails was not significant. The $\mathrm{Na}^{+} / \mathrm{K}^{+}$-ATPase activity in the 16-day ELF-MF exposed group of snails was $2.2 \times 10^{-6} \pm 0.6 \times 10^{-6} \mathrm{mmol} / \mathrm{mg} \times \mathrm{min}$.

We also calculated $\mathrm{Na}^{+} / \mathrm{K}^{+}$-ATPase fraction in total ATPases for the control and exposed groups of snails. The difference between the values for the control (0.6 $\pm 0.1)$, 7-day treated group $(0.5 \pm 0.1)$ and the 16 -day ELF-MF treated snails $(0.4 \pm 0.1)$ is not significant.

Figure 4, 5 Effect of the tested ELF-MF on the specific activity of the acid phosphatase is presented in Figure 5. ELF-MF applied for 7 days caused a significant increase $(\mathrm{p}<0.001, \mathrm{n}=3)$ in the activity of acid phosphatase $\left(6.8 \times 10^{-7} \pm 1.3 \times 10^{-7} \mathrm{mmol} /\right.$ $\mathrm{mg} \times \mathrm{min})$ compared to the control group of snails $\left(0.5 \times 10^{-7} \pm 2.5 \times 10^{-9} \mathrm{mmol} / \mathrm{mg} \times \mathrm{min}\right)$. A statistically significant decrease in acid phosphatase activity was 


\section{Total ATPases, Na,K-ATPase}

\section{Acid phosphatase}

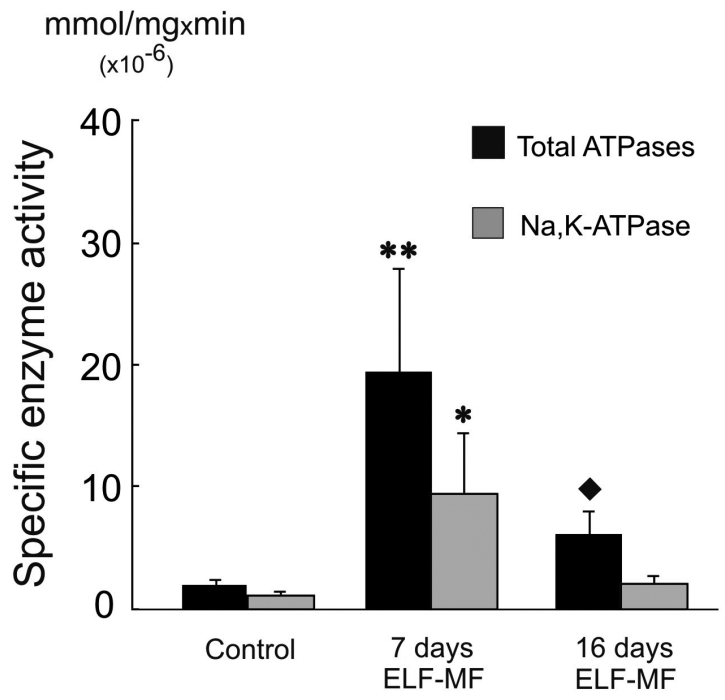

Figure 4. Specific activity of the total ATPases and $\mathrm{Na}$, KATPase in the control $(n=5)$, 7-day $(n=3)$, and 16day $(n=4)$ ELF-MF $(50 \mathrm{~Hz}, 0.5 \mathrm{mT})$ exposed group of snails, presented as mean \pm SEM. Note that the scaling factor on the $y$ axis is $10^{-6}$. ${ }^{*} \mathrm{p}<0.05$ and ${ }^{* *} \mathrm{p}<0.01$ indicate significant differences between control (7-day sham exposed) and 7-day ELF-MF exposed group of snails. $\downarrow 0.05$ indicates significant difference between 7 and 16-day ELF-MF exposed group of snails (one-way ANOVA, Fisher LSD test).

found in the 16-day exposed group $\left(3.9 \times 10^{-7} \pm 1 \times 10^{-}\right.$ $7 \mathrm{mmol} / \mathrm{mg} \times \mathrm{min}$ ) compared to the 7 -day exposed group of snails $(\mathrm{p}<0.05, \mathrm{n}=4)$.

\section{DISCUSSION}

In the present work, performed on Helix pomatia isolated ganglions, we showed that exposure of snails to the ELF-MF for a period of 7 days increased intracellular $\mathrm{pH}$ value and caused changes in the activity of the total ATPases, $\mathrm{Na}^{+} / \mathrm{K}^{+}$-ATPase and acid phosphatase, enzymes involved in phosphate turnover. Another important finding of our research is the difference between the effect of 7 and 16 days of ELF-MF exposure on snail phosphate metabolism. The level of phosphate compounds, PCr and ATP, as well as the activity of investigated enzymes, decreased in the16-day treatment group of snails, compared to the 7-day treatment group.

Two alternative explanations can be proposed for the obtained ${ }^{31} \mathrm{P}$ NMR spectrum of ganglia from the 7-day treatment group of snails. The first is that the tested ELF-MF did not cause changes in the

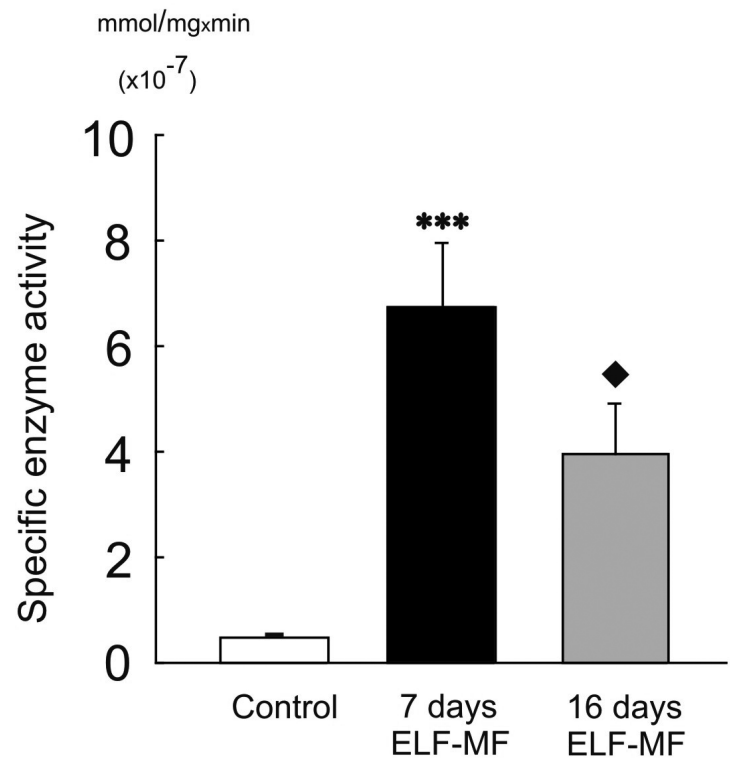

Figure 5. Specific activity of acid phosphatase in the control $(n=5)$, 7-day $(n=3)$ and 16-day $(n=4)$ ELFMF $(50 \mathrm{~Hz}, 0.5 \mathrm{mT})$ exposed groups of snails, presented as mean \pm SEM. Note that the scaling factor on the $y$ axis is $10^{-7}$. ${ }^{* * *} p<0.001$ indicates significant differences between control (7-day sham exposed) and 7-day ELF-MF exposed group of snails. $<0.05$ indicates significant difference between 7 and 16-day ELF-MF exposed group of snails (one-way ANOVA, Fisher LSD test).

metabolism of identified phosphate compounds in the snail nervous system. As can be seen from Figure 3, we did not find prominent changes in the intensities of PME, $\mathrm{Pi}, \mathrm{PCr}$ and ATP signals. The second explanation of the apparent lack of change in the ${ }^{31} \mathrm{P}$ NMR spectrum of snail ganglia after exposure to ELF-MF for 7 days is that an increase in both synthesis and the degradation of phosphate compounds occurred. We find the second explanation more plausible, since the increase in the activity of total ATPases and $\mathrm{Na}^{+} / \mathrm{K}^{+}$-ATPase, as found in the 7-day treatment group, should result in a decrease of ATP signal intensity, and we did not detect this by ${ }^{31} \mathrm{P}$ NMR. We interpret this finding as an indicator that metabolic pathways involved in the synthesis of ATP increased in the ganglia from the 7-day treatment group. Furthermore, the detected increase of acid phosphatase activity, involved in the processes of catabolism (Hollander, 1971), in the 7-day ELF-MF treatment group of snails indicates that the processes of catabolism of phosphate compounds in the snail nervous system increased.

A longer period of magnetic field exposure, according to our ${ }^{31} \mathrm{P}$ NMR data, decreased the 
level of energy source compounds ATP and PCr. Depressed ATP levels were also reported in experiments where rat brains were subjected to low frequency microwaves (Sanders et al., 1980; Sanders and Joines, 1984) and in the experiments with 60 $\mathrm{Hz}$ sinusoidal magnetic field on Physarum amoeba (Marron et al., 1986). Overall, our data suggest that magnetic fields probably cause a transient increase in the activity of enzymes involved in the synthesis of ATP, followed by the decrease in their activity with prolonged exposure.

The increase of the $\mathrm{Na}^{+} / \mathrm{K}^{+}$-ATPase activity, which we found after exposure to ELF-MF in vivo, is in agreement with the results of the ELF-MF effect on the $\mathrm{Na}^{+} / \mathrm{K}^{+}$-ATPase activity obtained on the isolated enzyme preparations. The in vitro effect of $60 \mathrm{~Hz}$ magnetic field was reported for the $\mathrm{Na}^{+}$/ $\mathrm{K}^{+}$-ATPase containing vesicles prepared from frozen rabbit kidneys (Blank and Soo, 1996). The increase in the activity of $\mathrm{Na}^{+} / \mathrm{K}^{+}$-ATPase, found in both, in vivo and in vitro research, indicates that ELF-MF interactions with biological systems as reflected in this enzyme activity might be at the protein level.

Recent research showed that the $0.5 \mathrm{mT} 60 \mathrm{~Hz}$ magnetic field can increase the activity of $\mathrm{F}_{0} \mathrm{~F}_{1}$ ATPase in chromatophores prepared from the cells of bacteria Rhodospirillum rubrum (Chen et al., 2009). The $\mathrm{F}_{0} \mathrm{~F}_{1}$-ATPase is also present in the inner membrane of eukaryotic mitochondria. To what extent this mitochondrial level of the ELF-MFbiological system interaction has a determining role in the complex phenomena whose net results we measured, needs to be further explored.

The prominent decrease after 16 days exposure at the level of PCr, which serves as the source of ATP (Mellergard and Siesjo, 1998) suggests that long exposure most probably affected an energy demanding cellular processes, such as gene transcription and protein synthesis. Therefore, the possibility of magnetic field-biological system interaction on the gene level should not be excluded.

We found that with longer exposure to ELF-MF in comparison to 7 days ELF-MF treatment there was a significant decrease in the activity of total ATPases and acid phosphatase. Even though it seems that some compensatory mechanism is in place, it is hard to say what levels and mechanisms of the regulation of enzyme activity are involved. Although it is quite possible that long term effects of ELF-MF exposure involve some gene transcription and translation changes that was not the object of our present study.

Finally, on the basis of the results obtained, we propose that exposure to the ELF-MF for the period of 7 days increased the overall phosphate turnover in the snail nervous system, while after prolonged ELF-MF exposure phosphate metabolism adjusted to the tested ELF-MF by reaching a balance at the new level. Most probably, more than one level of magnetic field-biological system interaction is involved in the detected perturbations of the phosphate metabolism.

Several aspects of nervous system energy status after exposure to ELF-MF in vivo were measured in this study. The results presented here, to our knowledge, are the first description of the ELFMF influence on the phosphate metabolism in the nervous system of Helix pomatia. We have found that the magnetic field induced an increase in the consumption of phosphate compounds and altered the activity of some enzymes involved in phosphate turnover. Together with in vitro conducted research, it could contribute to further understanding of the magnetic field - biological systems interactions.

\section{ACKNOWLEDGEMENTS}

This study was supported by the Ministry of Science and Technological Development, Republic of Serbia (Grants No. 143027 and 143016). The authors thank Dr. Branka Janać of the Institute of Biological Research "Siniša Stanković", Belgrade, for fruitful discussion during manuscript preparation.

\section{REFERENCES}

ALTRUP U (2004) Epileptogenicity and epileptic activity: mechanisms in an invertebrate model nervous system. Curr Drug Targets 5:473-84.

AYRAPETYAN SN, HUNANYAN AS, HAKOBYAN SN (2004) $4 \mathrm{~Hz}$ EMF treated physiological solution depresses Achinduced neuromembrane current. Bioelectromagnetics 25:397-399.

BALABAN PM, BRAVARENKO NI, KUZNETZOV A N (1990) Influence of a stationary magnetic field on bioelectric properties of snail neurons. Bioelectromagnetics 11:13-25.

BIANCHINI L, POUSSEGUR J (1994) Molecular structure and regulation of vertebrate $\mathrm{Na}^{+} / \mathrm{H}^{+}$exchangers. J Exp Biol 196:337-345.

BLAKEMORE RP (1982) Magnetotactic bacteria. Annu Rev Microbiol 36:217-238.

BLANK M, SOO L (1996) The threshold for Na,K-ATPase stimulation by electromagnetic fields. Bioelectroch Bioener 40:63-65.

Bradford MM (1976)

A rapid and sensitive method for the quantitation of microgram quantities of protein utilizing the principle of protein-dye binding. Anal Biochem 72: 248-254.

BUCK L, ESPANOL M, LITT L, BICKLER P (1998) Reversible decreases in ATP and $\mathrm{PCr}$ concentrations in anoxic turtle brain. Comp Biochem Physiol A Mol Integr Physiol 120:633-639.

CALVO AC, AZANZA MJ (1999) Synaptic neuron activity under applied $50 \mathrm{~Hz}$ alternating magnetic fields. Comp Biochem Physiol C Pharmacol Toxicol Endocrinol 124:99-107.

CHEN C, CUI Y, YUE J, HUO X, SONG T (2009) Enhancement of the hydrolysis activity of $\mathrm{F}(0) \mathrm{F}(1)$-ATPases using $60 \mathrm{~Hz}$ magnetic fields. Bioelectromagnetics, in press.

CIOMBOR DM, LESTER G, AARON RK, NEAME P, CATERSON B (2002) Low frequency EMF regulates chondrocyte differentiation and expression of matrix proteins. J Orthop Res 20:40-50. 
CRIDLAND NA, SABOUR NR, SAUNDERS RD (1999) Effects of $50 \mathrm{~Hz}$ magnetic field exposure on the rate of RNA synthesis by normal human fibroblasts. Int J Radiat Biol 75:647-654.

FABRY ME, SAN GEORGE RC (1983) Effect of magnetic susceptibility on nuclear magnetic resonance signals arising from red cells: a warning. Biochemistry 22:4119-4125.

HIRAI T, NAKAMICH, N, YONEDA Y (2002) Activator protein-1 complex expressed by magnetism in cultured rat hippocampal neurons.

Biochem Biophys Res Commun. 292:200-207.

HOLLANDER VP (1971) Acid phosphatase. In: Boyer PD (ed) The Enzymes, Vol. 4. New York: Acad. Press, pp 449-498.

JANAC B, PESIC V, JELENKOVIC A, VOROBYOV V, PROLIC Z (2005) Different effects of chronic exposure to ELF magnetic field on spontaneous and amphetamine-induced locomotor and stereotypic activities in rats. Brain Res Bull 67:498-503.

JELENKOVIC A, JANAC B, PESIC V, JOVANOVIC DM, VASILJEVIC I, PROLIC Z (2006) Effects of extremely lowfrequency magnetic field in the brain of rats. Brain Res Bull 68: 355-360.

KATZ Y, YILKS I (1979) Orientation of the European robin (Erithacus rubecula) in the planetarium at shifted stellar and magnetic meridians and at various rotation and decline angles of the polar axis. Zool J 58:197-206.

KAUPPINEN RA, WILLIAMS SR (1994) Nuclear magnetic resonance spectroscopy studies of the brain. Prog Neurobiol 44:87-118.

LARA J, ACEVEDO JJ, ONETTI CG (1999) Large-conductance Ca2+-activated potassium channels in secretory neurons. J Neurophysiol 82:1317-1325.

LIBOFF AR, CHERNG S, JENROW KA, BULL A (2003) Calmodulin-dependent cyclic nucleotide phosphodiesterase activity is altered by 20 microT magnetostatic fields. Bioelectromagnetics 24:32-38.

LOHMANN KJ, WILLOWS AOD (1991) An identifiable molluscan neuron responds to changes in earth-strength magnetic fields. J Exp Biol 161:1-24.

MAGISTRETTI PJ (2003) Brain energy metabolism. In: Squire LR (ed.): Fundamental neuroscience, Chapter 13. USA: Academic Press, pp 339-360.

MARRON MT, GOODMAN EM, GREENEBAUM B, TIPNIS P (1986) Effects of sinusoidal $60 \mathrm{~Hz}$ electric and magnetic fields on ATP and oxygen levels in the slime mold,

Physarum polycephalum. Bioelectromagnetics 7:307-314.

MATHER JG, BAKER RR (1981) Magnetic sense of direction in wood mice for route based navigation. Nature 291:152-155.

MATHIS A, MOORE FR (1984) Geomagnetism and the homeward orientation of the box turtle, Terrapene carolina. Ethology 78:265-274.

MCLEAN MJ, HOLCOMB RR, WAMIL AW, PICKETT JD, CAVOPOL AV (1995) Blockade of sensory neuron action potentials by a static magnetic field in the $10 \mathrm{mT}$ range. Bioelectromagnetics 16:20-32.

McNAMARA R, ARIAS-MENDOZA F, BROWN TR (1994) Investigation of broad resonances in 31P NMR spectra of the human brain in vivo. NMR Biomed 7:237-242.

MELLERGARD P, SIESJO BK (1998) Cerebral energy metabolism and pH. In Kaila K, Ransom BR (eds.): $\mathrm{pH}$ and brain function, Chapter 5. Wiley-IEEE, pp 67-95.

MIMURA T, KIRINO Y (1984) Changes in cytoplasmic pH measured by 31P-NMR in cells of Nitellopsis obtuse. Plant \& Cell Physiol 25:813-820.

MOGHADAM MK, FIROOZABADI SM, JANAHMADI M (2008) $50 \mathrm{~Hz}$ alternating extremely low frequency magnetic fields affect excitability, firing and action potential shape through interaction with ionic channels in snail neurons. Environmentalist 28:341-347.

NIKOLI $\square$ LJ, KARTELIJA G, NEDELJKOVI $\square$ M (2008) Effect of static magnetic fields on bioelectric properties of the $\mathrm{Br}$ and N(1) neurons of snail Helix pomatia. Comp Biochem Physiol A Mol Integr Physiol 151:657-663.

NOSSOL B, BUSE G, SILNY J (1993) Influence of weak static and $50 \mathrm{~Hz}$ magnetic fields on the redox activity of cytochrome-C oxidase. Bioelectromagnetics 14:361-372.

OHNISHI T, GALL RS, MAYER ML (1975) An improved assay of inorganic phosphate in the presence of extralabile phosphate compounds: application to the ATPase assay in the presence of phosphocreatine. Anal Biochem 69:261-267.

PERIĆ-MATARUGA V, PROLIĆ Z, NENADOVIĆ V, VLAHOVIĆ M, MRDAKOVIĆ M (2008) The effect of a static magnetic field on the morphometric characteristics of neurosecretory neurons and corpora allata in the pupae of yellow mealworm Tenebrio molitor (Tenebrionidae). Int J Radiat Biol 84:91-98

PRATO FS, KAVALIERS M, CARSON JJL (1996) Behavioral responses to magnetic fields by land snails are dependent on both magnetic field direction and light. Proc R Soc Lond B 263:1437-1442.

ROSEN AD (1992) Magnetic field influence on acetylcholine release at the neuromuscular junction. Am J Physiol Cell Physiol 262:1418-1422.

ROZSA KS (1984) The pharmacology of molluscan neurons. Progress in Neurobiology. 23:79-150.

RUDOLPH K, KRAUCHI K, WIRZ-JUSTICE A, FEER H (1985) Weak $50-\mathrm{Hz}$ electromagnetic fields activate rat open field behavior. Physiol Behav 35:505-508.

SANDERS AP, SCHAEFER DJ, JOINES WT (1980) Microwave effects on energy metabolism of rat brain. Bioelectromagnetics 1:171-181.

SANDERS AP, JOINES WT (1984) The effects of hyperthermia and hyperthermia plus microwaves on rat brain energy metabolism. Bioelectromagnetics 5:63-70.

SCHMITZ C, KELLER E, FREUDING T, SILNY J, KORR H (2004) $50-\mathrm{Hz}$ magnetic field exposure influences DNA repair and mitochondrial DNA synthesis of distinct cell types in brain and kidney of adult mice. Acta Neuropathol (Berl) 107:257-264.

SHEN JF, CHAO YL, DU L (2007) Effects of static magnetic fields on the voltage-gated potassium channel currents in trigeminal root ganglion neurons. Neurosci Lett 415:164168.

STUBBS M, VAN DEN BOOGAART A, BASHFORD CL, MIRANDA PM, RODRIGUES LM, HOWE FA, GRIFFITHS JR (1996) ${ }^{31} \mathrm{P}$-magnetic resonance spectroscopy studies of nucleated and non-nucleated erythrocytes; time domain data analysis (VARPRO) incorporating prior knowledge can give information on the binding of ADP. Biochim Biophys Acta 1291:143-148.

TODOROVIĆ D, KALAUZI A, PROLIĆ Z, JOVIĆ M MUTAVDŽIĆ D (2007) A method for detecting the effect of magnetic field on activity changes of neuronal populations of Morimus funereus (Coleoptera, Cerambycidae). Bielectromagnetics 28:238-241.

TSAO JW, PARAMANANTHAN N, PARKES HG, DUNN JF (1999) Altered brain metabolism in the C57BL/Wld mouse strain detected by magnetic resonance spectroscopy: association with delayed Wallerian degeneration? J Neurol Sci 168:1-12.

TSUJI M, ALLRED E, JENSEN F, HOLTZMAN D (1995) Phosphocreatine and ATP regulation in the hypoxic developing rat brain. Brain Res Dev Brain Res 85:192-200.

WANG JH, CAIN SD, LOHMANN KJ (2002) Identification of magnetically responsive neurons in the marine mollusk Tritonia diomedea. J Exp Biol 206:381-388.

YE SR, YANG JW, CHEN CM (2004) Effect of static magnetic fields on the amplitude of action potential in the lateral giant neuron of crayfish. Int J Radiat Biol 80:699-708.

ZOEGER J, DUNN JR, FULLER M (1981) Magnetic material in the head of the common Pacific dolphin. Science 213:892-894. 